\title{
The Impact of Water Deficit on The Soybean (Glycine max L.) Reproductive Stage of Development
}

\author{
Z. Miladinov, I. Maksimovic ${ }^{1}$, S. Balesevic Tubic, J. Miladinovic, V. Djordevic, M.Vasiljevic, V. Radic
}

10.18805/LR-517

\begin{abstract}
Experiment was conducted in 2014, 2015 and 2016 at the Institute of Field and Vegetable Crops, Novi Sad, Serbia, to study the effects of water deficit treatments during a soybean reproductive stage. Two water deficit treatments were conducted $T_{1}$ (from beginning of blossom to seed maturation) and $T_{2}$ (from beginning of seed filling to seed maturation period) and control (no water deficit). The results showed that water deficit during seed formation has a significant effect on germination energy, germination precentage and abnormal seedling. Obtained results are of great importance for farmers, because under favorable conditions, a large number of abnormal seedling has the ability to sprout, reach the reproductive stage and participate in yield formation.
\end{abstract}

Key words: Germination, Glycine max L., Reproductive stage, Water deficit.

\section{INTRODUCTION}

Water is considered as one of the most important environmental factors, that reduces crop productivity more than any other factor (Lambers et al., 2008). Plant response on water deficiency is very complex trait that includes genetic, morphological, physiological and biochemical mechanism (Saxena et al., 2019). Soybean is very sensitive to water deficit at certain stages of development and impact of water deficit depends on its length and intensity (Shadakshari et al., 2014). Magdi et al. (2017) found that the water deficit during blossom stage and the beginning of seed formation significantly increased the rate of abortion of pods. Water deficit during the late reproductive stage affects the accelerated leaf aging, (Sionit and Kramer, 1977) which leads to a decrease in yield (Núñez et al., 2005).

From all of the above it can be seen that the authors mainly examined impact of water deficit at certain stages of development. However, in production stage water deficit is not only related to one physiological stage of plant development. Therefore, the study of water deficit impact during a longer period of time (in stages where soybean in field conditions are most often exposed to water deficit) on quality of the formed seed, has significance for agricultural producers.

\section{MATERIALS AND METHODS Weather conditions}

Experiment was conducted in 2014, 2015 and 2016 in the semi-controlled conditions, at the Institute of Field and Vegetable Crops, Novi Sad, Serbia. The average daily temperature during experiment did not differ significantly in three years of the study. In 2014, the mean decadal temperature was $20.09^{\circ} \mathrm{C}$, in $2015,21.76^{\circ} \mathrm{C}$ and in 2016 , $20.98^{\circ} \mathrm{C}$. Data was taken from Republic Hydrometeorological Service of Serbia.

\section{Plant materials}

Experiment was set up in Mitcherlich pots (a total of 105
Department for Soybean, Institute of Field and Vegetable Crops, 21000 Novi Sad, Serbia.

Corresponding Author: Z. Miladinov, Department for Soybean, Institute of Field and Vegetable Crops, 21000 Novi Sad, Serbia. Email: zlatica.miladinov@ifvcns.ns.ac.rs

How to cite this article: Miladinov, Z., Maksimovic, I., Tubic, S.B., Miladinovic, J., Djordevic, V., Vasiljevic, M. and Radic, V. (2020). The Impact of Water Deficit on The Soybean (Glycine max L.) Reproductive Stage of Development. Legume Research. 43(5): 693-697.

Submitted: 10-07-2019 Accepted: 06-11-2019 Published: 17-03-2020

pots, with 5 plants per pot) by random block system in three replications. All plants were under the same irrigation layout (80\% FWC) until the beginning of flowering. Plants from 35 pots were exposed to water deficit $(60-65 \% \mathrm{FWC})$ from the beginning of flowering ( $\mathrm{R} 1$ soybean reproductive stage) until the end of the maturation period $\left(T_{1}\right)$. Plants from other 35 pots were exposed to the soil drought of the same intensity (60-65\% FWC) from the beginning of the seed filling (R5 soybean reproductive stage) until the end of the maturation period $\left(\mathrm{T}_{2}\right)$. Plants from the remaining 35 pots were optimally (80\% FWC) provided with water during the whole reproductive period (Control). During the vegetative period, in all years of research, on soybean plants have not been identified diseases, nor insect damage. Harvesting was done manually and then four average samples were formed for each treatment.

Germination energy and germination was tested using standard germination test and the cold test (ISTA, 1996). After eight days of germination, in soybean seedlings that germinated under optimal conditions (using standard germination test) was determined the intensity of lipid peroxidation was determined by the method of Placer et al. (1966), concentration of free proline by Bates (1973) method and vitamin C by Benderitter et al. (1998). Protein and oil content was determined by the NMR method (nuclear 
magnetic resonance) according to Granlund and Zimmerman (1975).

\section{Statistical analysis}

Data analysis was done using the statistical software package 'Statistica' (StatSoft, Inc., Tulsa, Oklahoma, USA). Obtained results were processed by method of three-way analysis of variance. Individual testing was carried out using Tukey's for the probability $p \leq 0.05$. The standard error of the arithmetic mean was used to calculate the significance of the difference using the Tuckey's test.The results presented in the graphs were obtained on the basis of oneway analysis of variance. The interval bars in the figures represent the difference between the standard error of the arithmetic mean.

\section{RESULTS AND DISCUSSION}

\section{Germination energy, germination, abnormal seedlings}

The water deficit in the reproductive stage had a negative impact on seed quality. The decrease in quality depended on the length of the water deficit. Under optimal temperature conditions, germination energy was $15 \%$ lower at $\mathrm{T}_{1}$ and $9 \%$ at $\mathrm{T}_{2}$, while germination was $9 \%$ and $6 \%$ lower, respectively (Fig 1,2). The negative effect of water deficiency is more pronounced, but without statistical significance, on germination in the case when the seeds are sown after harvest under stressful conditions or in conditions of lower temperature (Fig 3,4). There are contradictory results when it comes to the impact of water deficiency on seed germination. According to some scientists, the water deficit in the seed formation stage has a negative effect on its germination and according to other scientists it does not. Heatherly (1993), on the example of soybeans, found that a water deficiency influences on a decrease in seed quality, regardless of what period of the reproductive stage the plant was not sufficiently provided with water. Dornbos et al. (1989) found that with increasing water deficit, the period from the beginning of intensive seed filling and physiological maturity decreased from 17 to $27 \%$, with seed germination decreasing by $6 \%$. Smiciklas et al. (1989) state that seeds exposed to water deficit at the germination stage had $10 \%$ lower germination (86\%) compared to seeds that developed under conditions of optimal plant water supply (germination rate of $96 \%$ ). Contrary to these experiments, Vieira et al. (1992) found that lack of water during seed formation does not affect the decrease in its germination. Also, the results showed that the water deficit had a great influence on the content of abnormal seedling. Under optimal temperature conditions, the content of abnormal seedling was $9 \%$ higher at $\mathrm{T}_{1}$ and $5 \%$ higher than the control at $\mathrm{T}_{2}$ (Fig 5,6 ). Under stress conditions, only the $T_{2}$ variant showed a difference in the number of abnormal seedling, $3 \%$. Dead seeds were statistically significantly higher during germination under stress conditions, $11 \%$ and $4 \%$ respectively higher than controls. Abnormal seedlings are not counted as germinating seeds in the standard germination test, as it is assumed

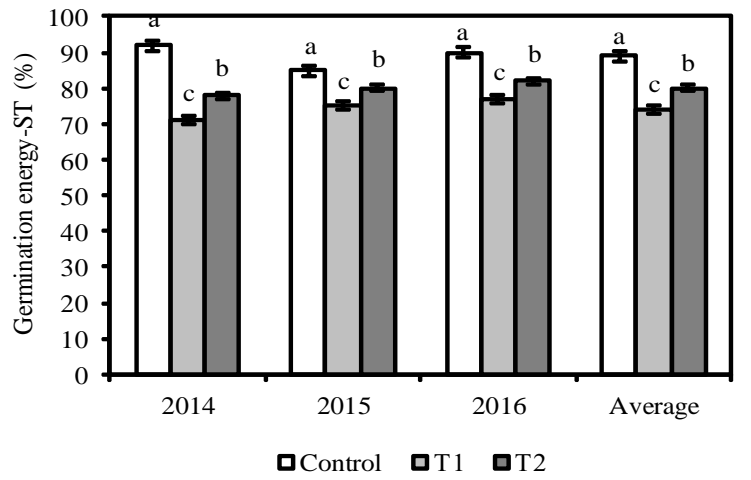

Fig 1: The effect of water deficit on germination energy (standard test).

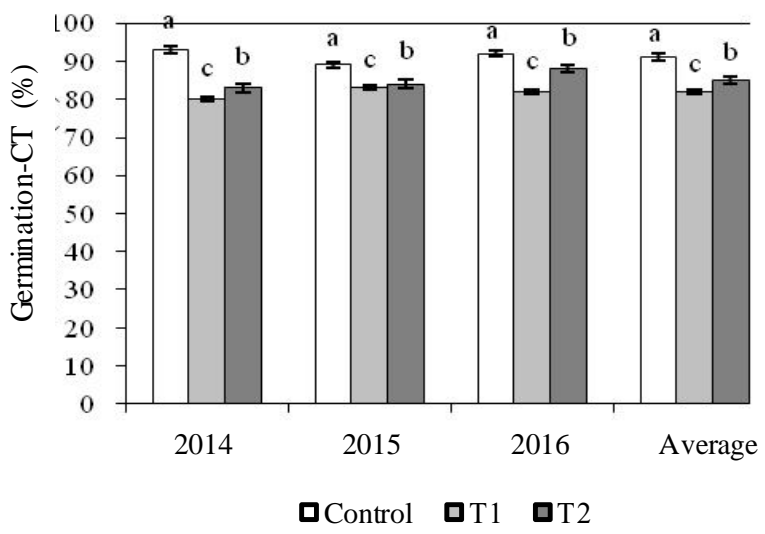

Fig 2: The effect of water deficit on germination energy (cold test).

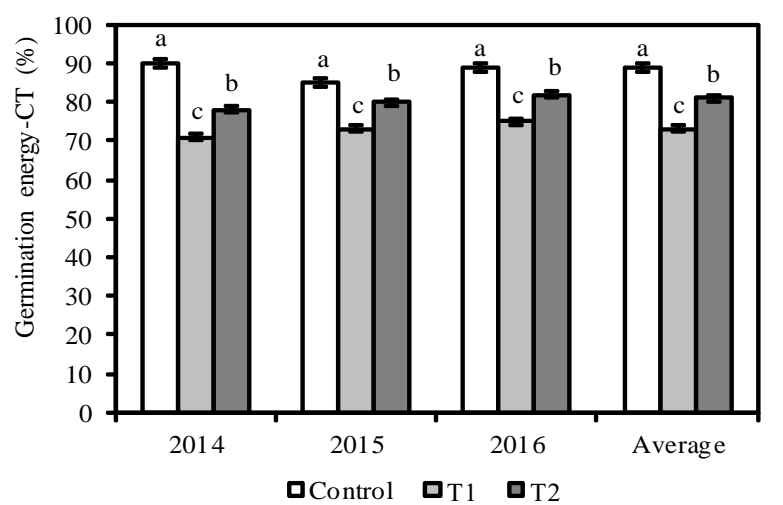

Fig 3: The effect of water deficit on germination (standard test).

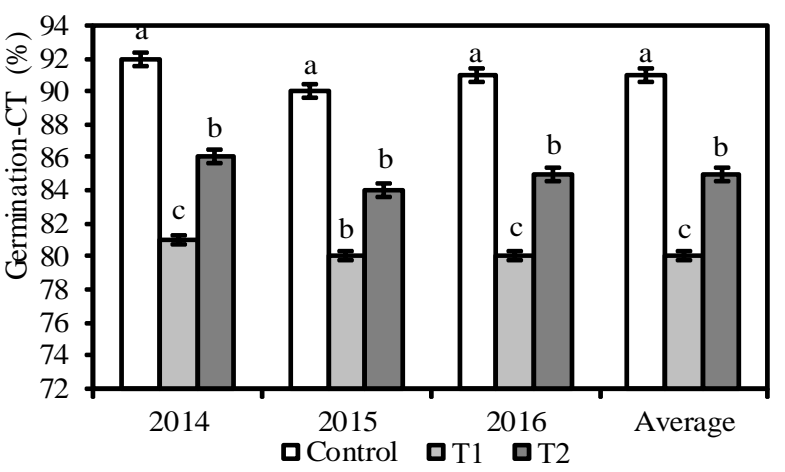

Fig 4: The effect of water deficit on germination (cold test). 
Impact of Water Deficit on The Soybean (Glycine max L.) Reproductive Stage of Development

that they will not yield a normal plant. However, according to experiments conducted on maize in favorable conditions, many abnormal seedlings have the ability to sprout, reach the reproductive stage and participate in yield formation (Vujošević et al., 2018). Seeds formed under water deficiency also have a high proportion of abnormal seedlings, if germination is performed under optimal germination conditions. However, if germination is carried out at low temperatures then a higher proportion of dead seeds is significantly higher than abnormal ones. The results are of great importance for farmers as they show that soybean seeds formed under water deficiency have the ability to germinate. However, with seeds like this there is a big difference between germination energy and seed germination. The reason is that such seeds need more time to absorb water and imbibition, resulting in slow seed germination.

\section{Biochemical parameters in seedlings}

With the increase in the length of the water deficit, there was an increase in the intensity of lipid peroxidation, the content of free proline and vitamin $\mathrm{C}$ in soybean seeds. The $T_{1}$ variant had an increase of $15.74 \%$ and the $T_{2}$ variant of $8.13 \%$ higher intensity of lipid peroxidation, while the free proline content increased by about three and two times, respectively, in soybean seedlings compared to the control (Fig 7, 8). A similar conclusion was reached by Li et al. (2013) on the seeds of the plant Eremosparton songoricum (Litv.) Vass. They point out that a greater water deficit results in a more intense accumulation of MDA which results in damage to the cell membranes, resulting in a decrease in seed quality. A large body of data indicates a positive correlation between proline accumulation and plant stress caused by the action of one of the environmental factors. Free proline is an amino acid that plays a very important role in plants exposed to different stress conditions. In addition to acting as an excellent osmolyte, free proline plays three major roles during stress, ie. as a metal chelator, an antioxidant defense molecule and a signaling molecule (Hayat et al., 2012). Also, due to the effect of unfavorable environmental factors, a higher amount of vitamin $\mathrm{C}$ accumulates. A significantly higher amount of vitamin $\mathrm{C}$ was accumulated in seedlings from the $T_{1}$ variant, $50.90 \%$, while in the $\mathrm{T}_{2}$ variant, it was $25.65 \%$ more accumulated compared to the control (Fig 9). Tuteja et al. (2012) point out that an increase in vitamin $\mathrm{C}$ content is of great importance, especially in the case of legumes, which are very sensitive to the adverse influence of environmental factors. Vitamin $\mathrm{C}$ under unfavorable conditions has the ability to activate a complex of defense mechanisms and thus to reduce the negative effect of abiotic factors (Conklin, 2001).

\section{Chemical composition of seeds}

The protein and oil content of the seed depends primarily on the genetic factors, but also on the effect of environmental factors (Wilcox et al., 1985). This is confirmed by the results of the soybean research. The water deficit from the beginning

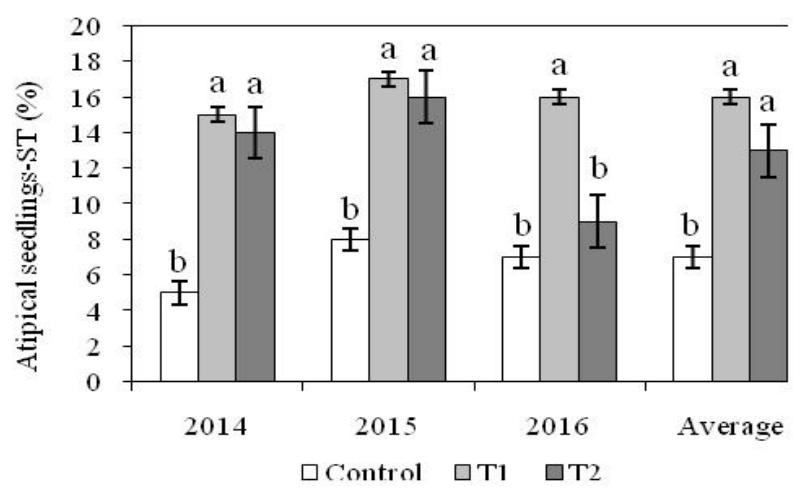

Fig 5: The effect of water deficit on atypical seedlings (standard test).

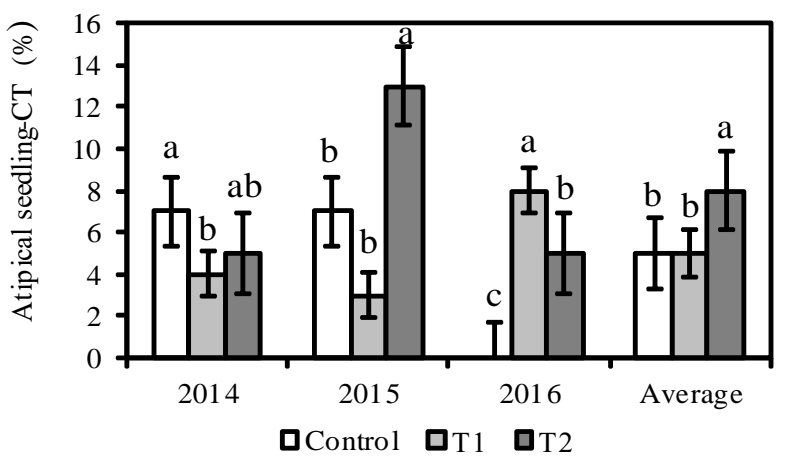

Fig 6: The effect of water deficit on atypical seedlings (cold test).

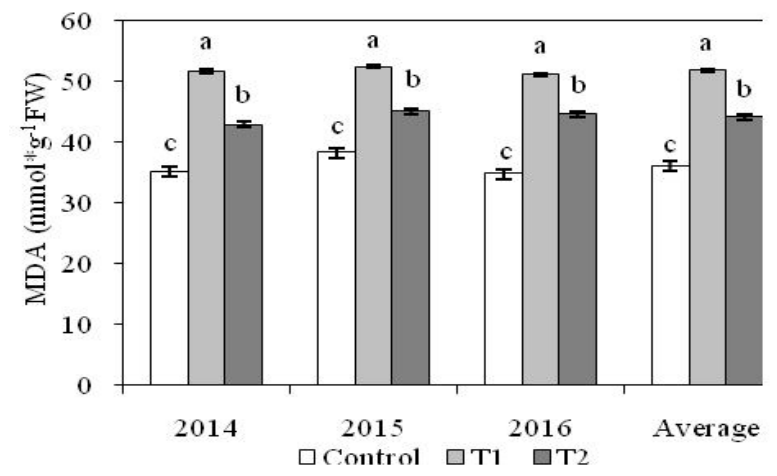

Fig 7: The effect of water deficit on MDA content.

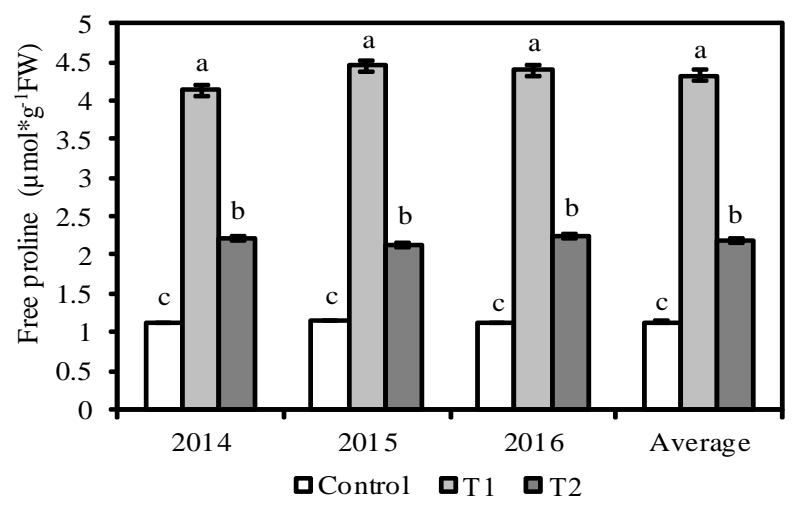

Fig 8: The effect of water deficit on content of free proline. 


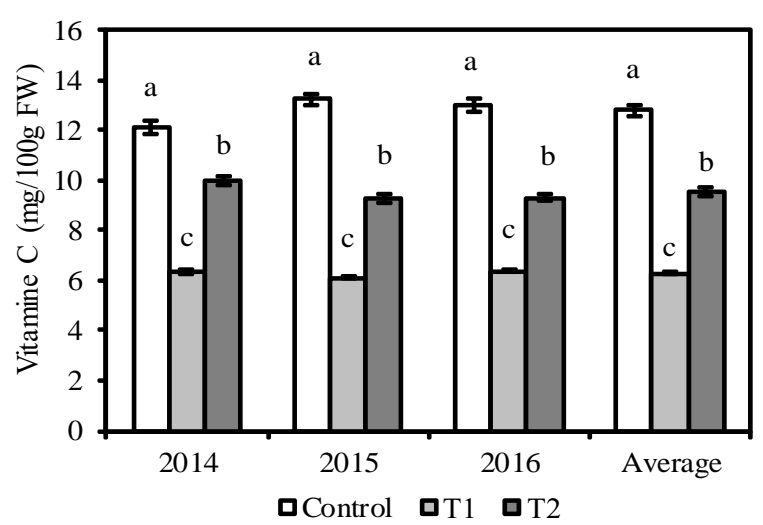

Fig 9: The effect of water deficit on content of vitamin C.

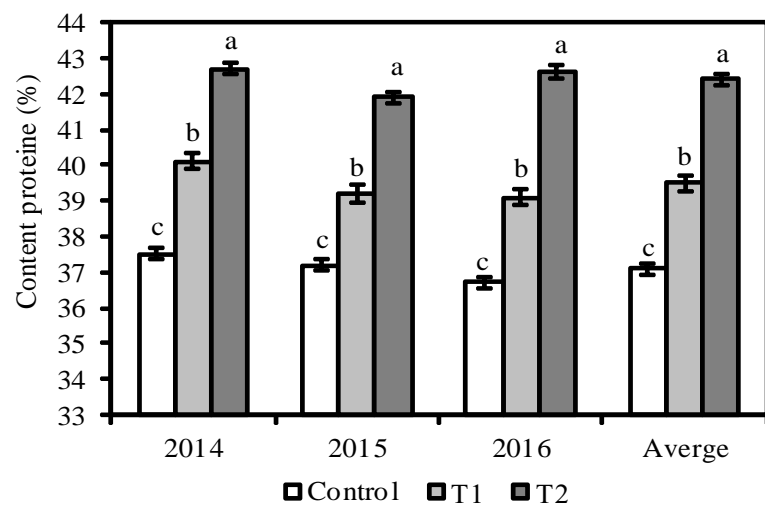

Fig 10: The effect of water deficit on the content of protein in soybean seed.

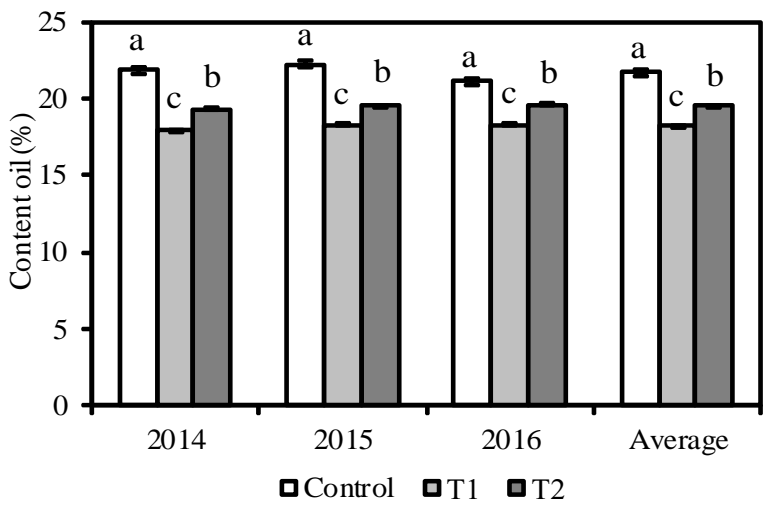

Fig 11: The effect of water deficit on oil content in soybean seed.

of flowering to the seed maturation stage had a greater effect on increasing the protein content than on reducing the oil content. Protein content was $42.4 \%$ in $\mathrm{T}_{1}, 39.5 \%$ in $\mathrm{T}_{2}$ and $18.2 \%$ and $19.5 \%$, respectively (Fig 10). Experiments have shown that plants exposed to the water deficit from the beginning of flowering to the end of the maturation period had a $5.3 \%$ higher protein content than plants that were optimally provided with water. The water deficit from the beginning of seed filling to the end of the maturation period increased the protein content by $2.9 \%$. The results are in agreement with the research conducted by Rotundo and Vestgate (2010). They found that the protein content increased by 2 to $23 \%$, depending on the length of the water deficit, relative to plants that were optimally provided with water. A similar conclusion was reached by Carrera et al. (2009). They point out that the protein content of soybean seeds, in addition to the length of the water deficit, also depends on the intensity of the water deficit. Lemaitre et al. (2008) found that, if there is a water deficit, the plant to a lesser extent absorbs nitrogen in the form of nitrate from the soil solution and for the most part it mobilizes from other plant parts to the seed as well as to the young leaves. Ozturk and Aydin (2004) found that the increase in protein content due to water deficit is mainly due to higher accumulation of nitrogen in the seed and lower accumulation of carbohydrates. Water deficit also led to a decrease in oil content. Plants exposed to the water deficit from the beginning of flowering to the end of the maturation period had a $3.2 \%$ lower oil content compared to plants that were optimally provided with water (Fig 11). Smiciklas et al. (1989) point out that the water deficit in the grain filling phase has the greatest influence on reducing the oil content.

\section{CONCLUSION}

Based on three years of research into the impact of the water deficit in the reproductive stage of soybean development, the following conclusions can be drawn:

- Seed quality is deteriorating and significant deterioration is present in seeds that are sown after harvest under stressful conditions or in the germination phase exposed to a lower temperature.

- Protein content increased while oil content decreased in water deficit conditions during the generative period. As the length of the water deficit increases, the effect is more pronounced.

- The intensity of lipid peroxidation, the content of free proline and vitamin $\mathrm{C}$ were increased in seedlings that originated from seeds formed under conditions of water deficit.

\section{ACKNOWLEDGEMENT}

This article is part of the project TR-31022 "Interdisciplinary Approach to Development of New Soybean Varieties and Improvement of the Cultivation Practices and Seed Production", financially supported by the Ministry of Education, Science and Technological Development of the Republic of Serbia. Also, this article is part the project 114451-2739/2016 Sustainable production of plant proteins: soybean, microorganisms, response to climate change" financially supported by the Provincial Secretariat for Science and Technological Development. We express our sincerest gratitude to them for support.

\section{REFERENCES}

Bates, L.S., Waklren, R.P., Teare, I.D. (1973). Rapid determination of free proline water stress studies. Plant and Soil. 39: 205-207.

Benderitter, M., Maupoli, V., Vergely, C., Dalloz, F., Briot, F., Rochette, L. (1998). Studies by electron paramagnetic resonance 
of the importance of iron in the hydroxyl scavenging properties of ascorbic acid in plasma: Effects of iron chelators. Fundamental and Clinical Pharmacology. 12: 510-516.

Carrera C., Martínez M. J., Dardanelli J., Balzarini M. (2009). Water deficit effect on the relationship between temperature during the seed fill period and soybean seed oil and protein concentrations. Crop Science. 49: 90-998.

Conklin P. L., Barth C. (2004). Ascorbic acid, a familiar small molecule intertwined in the response of plants to ozone, pathogens and the onset of senescence. Plant Cell. 27: 959-971.

Dornbos D. L., Mullen R. E., Shibles R. M. (1989). Drought stress effects during seed fill on soybean seed ger minat ion and vigor. Crop Science. 29: 476-480.

Granlund M., Zimmerman D. C. (1975). Effect of drying conditions on oil content of sunflower (Helianthus annuus L.) seeds as determined by wide line Nuclear Magnetic Resonance (NMR). Proceedings of the North Dakota Academy of Science. 27: 128-132.

Hayat S., Hayat Q., Alyemeni M. N., Wani A. S. Pichtel, J., Ahmad A. (2012). Role of proline under changing environments. Plant Signaling Behavior. 7(11): 1456-1466.

Heatherly L. G. (1993). Drought stress and irrigation effects on germination of harvested soybean seed. Crop Science. 33: 777-781.

ISTA (1996). International Rules for Seed Testing. Zurich: ISTA. [Lambers H., Chapin F., Pons T. (2008)]. Plant Physiological Ecology. Springer, New York, pp 540.

Li H. Y., Li X. S., Zhang D. Y., Liu H. L., Guan K. Y. (2013). Effects of drought stress on the seed germination and early seedling growth of the endemic desert plant Eremosparton songoricum (Fabaceae). Experimental and Clinical Sciences Journal. 12: 89-101.

Magdi A., Mousa À., Adel D. Al Qurashi À. D. (2018). Growth and yield of cowpea (Vigna unguiculata L.) cultivars under water deficit at different growth stages. Legume Research-An International Journal. 41: 702-709.
Ozturk A., Aydin F. (2004). Effect of water stress at various stages on some quality parameters of winter wheat. Crop Science. 190: 93-99.

Placer Z. A., Cushman L. L., Johnson B. C. (1966). Estimation of product of lipid peroxidation (malonyl dialdehyde) in biochemical systems. Analytical Biochemistry. 16: 359-364.

Rotundo J. L., Westgate, M. E. (2010). Rate and duration of seed component accumulation in water-stressed soybean. Crop Science. 50: 676-684.

Saxena S. N., Kakani R. K., Sharma L. K., Agarwal D., John S., Sharma Y. (2019). Effect of water stress on morphophysiological parameters of fenugreek (Trigonella foenumgraecum L.) genotypes. Legume Research-An International Journal. 42: 60-65.

Shadakshari T. V., Yathish K. R., Kalaimagal T., Gireesh C., Gangadhar K., Somappa J. (2014). Morphological response og soybean under water stress during pod development stage. Legume Research-An International Journal. 37:37-46.

Simiciklas K. D., Mullen R. E., Carlson R. E., Knapp A. D. (1989). Drought induced stress effects on soybean seed calcium and seed quality. Crop Science. 29: 1519-1523.

Sionit N., Kramer P. J. (1977). Effect of water stress during different stages of growth of soybeans. Agronomy Journal. 69: 274-278.

Tuteja N., Gill S. S., Tiburcio A. F., Tuteja R. (2012). Improving Crop Resistance to Abiotic Stress. Wiley-Blackwell; Weinheim: 10.

Vieira R.D., Tekrony D.M., Egli D.B. (1992). Effect of drought and defoliation stress in the filed on soybean seed germination and vigor. Crop Science. 32: 471-475.

Vujosevic B., Canak P., Babic M., Mirosavljevic M., Mitrovic B., Stanisavljevic D., Tatic M. (2018). Ponasanje atipicnih klijanaca kukuruza u poljskoj proizvodnji. Ratarstvo i povrtarstvo. 55: 34-38.

Wilcox J. R. (1985). Breeding soybean for improved protein quantity and quality. In: World Soybean Research Conference, III: Proceedings. [(Ed.) R Shibles, Boulder, CO], Westview Press, pp. 380-386. 